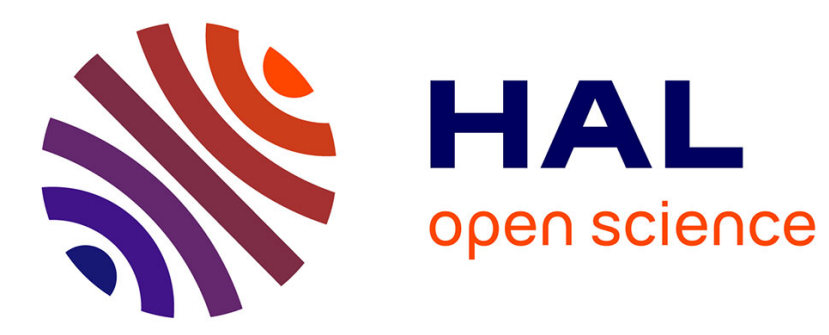

\title{
EPISTEMIC MODALITY AND PERFECT MORPHOLOGY IN SPANISH AND FRENCH
}

Brenda Laca

\section{To cite this version:}

Brenda Laca. EPISTEMIC MODALITY AND PERFECT MORPHOLOGY IN SPANISH AND FRENCH. 2016. hal-01372980

\section{HAL Id: hal-01372980 \\ https://hal.science/hal-01372980}

Preprint submitted on 28 Sep 2016

HAL is a multi-disciplinary open access archive for the deposit and dissemination of scientific research documents, whether they are published or not. The documents may come from teaching and research institutions in France or abroad, or from public or private research centers.
L'archive ouverte pluridisciplinaire HAL, est destinée au dépôt et à la diffusion de documents scientifiques de niveau recherche, publiés ou non, émanant des établissements d'enseignement et de recherche français ou étrangers, des laboratoires publics ou privés. 


\title{
EPISTEMIC MODALITY AND PERFECT MORPHOLOGY IN SPANISH AND FRENCH
}

\author{
Brenda Laca
}

In current approaches to the interaction between modality and temporality, there has been widespread consensus as to the fact that, in epistemic readings, modal verbs outscope tense and aspect (Condoravdi 2001, Hacquard 2006, Demirdache \& Uribe-Etxeberria 2006, 2008 among many others). This generalization, which is semantic in nature, conflicts with the actual realization of tense-aspect morphology on epistemically interpreted modal verbs, a regular phenomenon in languages in which modal verbs are transparently and fully inflected for TMA categories. Among these, the Romance languages figure prominently, and they have provided a number of researchers with evidence against the hypothesis according to which epistemic modals outscope tense and aspect (Boogart 2007, Mari 2015, Homer 2010, Martin 2011). In this contribution, I will concentrate on the interaction between modals and perfect morphology in French and Spanish, which can be shown to vary in an intriguing way. ${ }^{1}$

The paper is organized as follows: section 1 provides an introduction to temporal configurations in modal environments and to the characterization of epistemic readings; section 2 gives an overview of the interpretation of epistemic modals bearing past morphology; section 3 is devoted to the contrast between higher perfects and perfect infinitives in French and Spanish; section 4 concludes.

\section{INTRODUCTION. TEMPORAL CONFIGURATIONS AND EPISTEMIC READINGS.}

Interactions between modal verbs and tense-aspect morphology are extremely complex, and give rise to interpretive patterns that constitute a challenge to compositional approaches to interpretation; in fact, they look at first sight like instances of morphology gone awry. Such patterns, which are illustrated for Spanish below, comprise (i) multiple ambiguities, (ii) apparently redundant morphology, (iii) apparently equivalent different linearizations, and (iv) unexpected morphological equivalences.

(i) Multiple ambiguities

As shown by the English paraphrases, a sentence like (1), with a modal in the simple (perfective) past, has at least three distinct readings, which are arguably associated with different temporal configurations

\footnotetext{
${ }^{1}$ I'd like to thank the audiences at the Madrid Colloquium in honor of Ignacio Bosque (June 2015) and at the seminar on Tense and Modality in Montevideo (July 2015) for their insightful comments, and Zlatka Guentcheva and two anonymous reviewers for their suggestions. Abbreviations used in the glosses are as follows: COND= conditional, $\mathrm{IMPF}=$ imperfect(ive) past, $\mathrm{PP}=$ past participle, $\mathrm{SP}=$ simple (perfective) past.
} 
(1) El ladrón pudo entrar por la ventana.

the thief CAN.SP enter by the window

(i) The thief was able/managed to come in through the window. (IMPLICATIVE READING)

(ii) The thief had the opportunity/possibility to come in through the window (but he didn't). (COUNTERFACTUAL READING)

(iii) As far as I know, it might have been the case that the thief came in through the window (EPISTEMIC READING)

(ii) Redundant morphology

When a modal in the simple (perfective) past embeds a perfect infinitive, the sentences thus obtained (cf. (2)) preserve the counterfactual and epistemic readings of the sentences lacking a perfect infinitive, only the implicative reading disappears. For the admissible readings, perfect morphology on the infinitive seems to be redundant (see Bosque 1999).

(2) El ladrón pudo haber entrado por la ventana.

the thief CAN.SP have entered by the window

(i) The thief had the opportunity/possibility to come in through the window (but he didn't).

(COUNTERFACTUAL READING)

(ii) As far as I know, it might have been the case that the thief came in through the window (EPISTEMIC READING)

(iii) Equivalent linearizations

In the presence of conditional morphology, the site of realization of perfect morphology (on the modal in (3a) or on the infinitive in (3b)) does not seem to affect interpretation. For all practical purposes, (3a) and $(3 \mathrm{~b})$ are synonymous.

(3) a. María habría podido quedarse en México.

M. have.COND CAN.PP stay-REFL in Mexico

b. María podría haberse quedado en México.

M. CAN.COND have-REFL stayed in Mexico

'María could have stayed in Mexico'

(iv) Unexpected morphological equivalences

As all Romance languages, Spanish exhibits a very clear semantic contrast between the simple (perfective) past and the imperfect. However, in the counterfactual reading, which is the only one admitted by the context for sentences $(4 a)$ and $(4 b)$, both containing a perfect infinitive, this contrast seems to be neutralized. 
(4) Ella no te encerró con mil cerrojos. La casa estaba abierta.

'She didn't lock you under a thousand locks. The door was open'

a. Tú pudiste haber escapado.

you CAN.SP have escaped

b. Tú podías haber escapado.

you CAN.IMPF have escaped

'You could have escaped'

These patterns indicate that modal verbs interact with tense and aspect in a peculiar way, which is not parallelled by any other lexical items. As we will see, in the case of epistemic readings, which are the focus of this paper, it has been argued that this interaction is constrained by the impossibility of obtaining epistemic readings in certain temporal configurations, and by the near-obligatoriness of epistemic readings in certain other temporal configurations.

Temporal configurations in modal environments are more complex than they are in non-modal environments, because the former must determine not only the temporal location of the event or situation described in the sentence, but also the temporal location of the time of modal evaluation.2 Modalized sentences are interpreted against a background of possibilities (a set of worlds constituting the domain of quantification for the modal operator, henceforth modal base, see Kratzer 1981, Kaufmann, Condoravdi \& Harizanov 2006, Portner 2009 among many others), and possibilities change (actually diminish) with the flow of events in time. Just as the occurrence of any new event eliminates from a circumstancial/metaphysical modal base all the worlds in which the event does not occur, the acquisition of a piece of propositional knowledge eliminates from an epistemic modal base all the worlds in which the proposition is not verified. Thus, modal bases change inexorably with time, and the point in time from which a modal base is accessed (the time of modal evaluation) is never indifferent.

Condoravdi (2001) has considerably contributed to clarify the issue of temporal configurations in modal environments by distinguishing what she calls the temporal perspective (Tpersp) of the clause from its temporal orientation (Torient). Tpersp is a relationship between the time of modal evaluation (Tmod) and the highest anchor for tense, which is generally speech time (S) in main clauses and the time of the matrix (Tmatrix) in the object clauses of attitude verbs. Torient is the relationship between the time of the described situation/of the prejacent proposition (Tprej) and Tmod. ${ }^{3}$ Thus, sentences (5a) and (5b) both illustrate a past temporal orientation and a simultaneous temporal perspective, the difference between them being that in (5b) Tmod is simultaneous with Tmatrix, which is itself past.

2 As stated in Laca (2014), the complexity arises from the fact that this double temporal location has to be determined in monoclausal structures which, as such, have only one Tense projection.

3 Following a suggestion by von Fintel (2005), we call 'prejacent' the proposition which is the argument of the modal verb, i.e. the modalized proposition minus the modal expression. Some authors have suggested that a third relationship might be necessary in order to account for certain interpretations (Laca 2012, Martin 2011). 
(5) a. He must have left early.

\author{
TPersp: Tmod SIMUL S \\ TOrien: Tprej BEFORE Tmod \\ b. She thought that he must have left early. \\ Tmatrix BEFORE S \\ TPersp: Tmod SIMUL $\underline{\text { Tmatrix }}$ \\ TOrien: Tprej BEFORE Tmod
}

Such temporal configurations almost invariably give rise to epistemic readings. The explanation that may be invoked for this constraint has to do with the fact that past and present issues are objectively decided at the time of evaluation, whereas only the future contains open possibilities. Whenever the issue whether the prejacent is true or false is already objectively decided at Tmod, only the subjective uncertainty that goes hand in hand with epistemic readings is apt to ensure that the modal base is pdiverse, i.e. that it contains both worlds which verify the prejacent and worlds which don't. P-diversity is a pragmatic constraint on modal bases (and as such it may be circumvented in some cases), arguably motivated by a number of semantic anomalies that arise with non-p-diverse domains (cf. Condoravdi 2001, Werner 2003).

On the other hand, certain temporal configurations exclude epistemic readings. This is clearly the case in sentence (6a), which has a future temporal perspective and a future temporal orientation, and in (6b), which has a past temporal perspective and a future temporal orientation. Both sentences can only receive a root interpretation (obligation, requirement and the like):

(6)a. He'll have to leave early.

TPersp: Tmod AFTER S

\section{TOrien: Tprej AFTER Tmod}

b. He had to leave early.

\section{TPersp: Tmod BEFORE S}

\section{TOrien: Tprej AFTER Tmod}

In fact, syntactic approaches have claimed for the best part of three decades that the difference between epistemic and root modals is a difference in scope, with epistemic modals outscoping other operators, most notably tense and/or aspect (Picallo 1990, Cinque 1999, Butler 2003, Hacquard 2006). Semantic approaches, by contrast, claim that the unavailability of epistemic readings for (6a-b) is due to the fact that epistemic readings have to be anchored to the now of the relevant epistemic agent, which normally coincides with the speaker in main sentences (Papafragou 2005, Boogart 2007). Only a simultaneous temporal perspective could guarantee this anchoring.

The generalizations that emerge are thus:

1. Epistemic readings are the only available option when the temporal orientation is past or simultaneous (i.e. when the truth value of the prejacent is decided at the time of modal evaluation). The modals in examples (5a-b) can only have an epistemic reading because, their temporal orientation being past, the truth value of the prejacent is objectively decided at 
Tmod, and the requirement of p-diversity can only be fulfilled by the uncertainty of an epistemic agent as to this truth value.

2. Epistemic readings are impossible when the temporal perspective is not simultaneous. The modals in examples (6a-b) cannot have an epistemic reading because their temporal perspective is future, resp. past.

These generalizations can only be tested without circularity if we have a precise understanding of what epistemic readings are.

First and foremost, epistemic readings rely on the epistemic uncertainty of the relevant epistemic agent(s), and they are excluded whenever there is direct evidence for the truth of the prejacent (von Fintel \& Gilles 2007). Thus, (7) is acceptable in context (A), but it is not adequate in context (B):

(7) It must be raining outside.

A. Speaker sees people entering the buiding with umbrellas and wet shoes.

\#B. Speaker looks out of the window and sees the rain.

In epistemic readings, universal (necessity) modals mean that the prejacent is inferrable from the available evidence/from what is known and what is believed by the relevant epistemic agent. In fact, most assertions containing universal epistemic modals express abductive inferences (Desclés \& Guentcheva 2001), though deductive and inductive (probabilistic) inferences are not impossible. Existential (possibility) modals mean that the prejacent is not incompatible with the available evidence/with what is known or believed by the relevant epistemic agent.

(8) a.It must be raining outside.

'From the available evidence, Speaker concludes that it is raining outside'.

b. It may be raining outside.

'From the available evidence, Speaker cannot conclude that it isn't raining outside'

One of the most reliable tests for epistemic readings is the naturalness of continuations with tags like for all I know, or let's check, which target the issue of the truth value of the prejacent (and not of the whole modalized proposition).

\section{EPISTEMIC READINGS AND TENSE-ASPECT MORPHOLOGY}

Generalization (2) above has received a syntactic explanation in line with the general tendency for epistemic modals to have wider scope than other operators. For some authors, epistemic modals obligatorily outscope tense and/or aspect either because they are base generated at a higher position (Picallo 1990, Butler 2003, Cinque 1999, Hacquard 2006) or as the result of movement (Demirdache \& Uribe-Etxeberria 2006, 2008). This syntactic explanation is challenged by overtly realized and interpretable tense-aspect morphology on the modal verb.

So, for instance, cases in which the temporal perspective is simultaneous, but there are nonetheless interpretable morphological contrasts in tense-aspect morphology, show that a semantic- 
pragmatic account fares better than the syntactic explanation. The contrast between modals in the present tense and modals in the imperfect in embedded contexts in Romance languages is one of these cases. In fact, this contrast replicates an identical contrast in non-modalized sentences. In languages exhibiting sequence of tense, a present tense embedded under the past form of an attitude or speech-act verb gives rise to a so called "double-access" reading, in which the time of the complement clause is simultaneous to both the time of the attitude and to speech time. By contrast, an imperfect only requires simultaneity to the (past) time of the attitude. This is the reason why (9a) is strange, since it requires a duration of pregnancy which largely exceeds what world knowledge dictates, whereas $(9 \mathrm{~b})$ is perfect:

(9) a. \#Juan me dijo hace un año que María está embarazada.

J. me tell.SP make a year that M. be.PRES pregnant

'Juan told me a year ago that Maria is pregnant'

b. Juan me dijo hace un año que María estaba embarazada.

J. me tell.SP make a year that M. be.IMPF pregnant

'Juan told be a year ago that María was pregnant'

In languages exhibiting sequence of tense, present tense is deictic in nature, whereas there is a dedicated anaphoric tense, corresponding in Romance to the imperfect, which can express simultaneity to a past attitude. Now, this contrast is preserved when the complement clause contains an epistemic modal:

(10) a. \#Juan me dijo hace un año que María debe estar embarazada.

J. me tell.SP make a year that M. MUST.PRES be pregnant

'Juan told me a year ago that María must be pregnant'

b. Juan me dijo hace un año que María debía estar embarazada.

J. me tell.SP make a year that M. MUST.IMPF be pregnant

'Juan told me a year ago that María must be pregnant'

From this we conclude - against the syntactic hypothesis - that modal verbs in epistemic readings may be dominated by a projection which at the very least distinguishes between a deictic and an anaphoric tense. This projection cannot but be the tense projection. 4

The anaphoric interpretation of imperfect morphology on an epistemic modal is also available in main clauses, i.e. in the absence of overt embedding under a past attitude verb. Thus, in (11a), it is the (past) thoughts of Marie when she checks the time that are being reported, and (11b) reports the (past) thoughts of the parents when learning about the facts:

\footnotetext{
${ }^{4}$ See also Homer (2010), who argues in favor of the presence of tense above epistemic modals on the grounds of scopal interaction with other operators, such as negation. Homer's reasoning is the following: the epistemic existential modal pouvoir 'can' always scopes under negation, tense is known to scope above negation, so it follows by scope transitivity that the epistemic existential modal must scope under tense.
} 
(11) a. Marie regarda sa montre. Il était très tard.

[FRENCH]

Pierre devait s'inquièter de son absence.

Pierre MUST.IMPF REFL-worry of her absence

'Marie looked at her watch. It was very late. Pierre must be worrying that she was not there'

b. Cuando los padres se enteraron, montaron en furia, la golpearon sin piedad

[SPAN.]

y no le permitieron explicar los reales hechos.

Decididamente, la cosa tenía que haber sucedido tal como la gente decía.

decidedly the thing HAVE.IMPF that have happened such as the people say.IMPF

La culpa de todo debía tenerla ella.

the guilt of all MUST.IMPF have+it she.

[Dimas Aranda, S. Tiempo de agonía <http://www.biblioteca.org.ar/libros/88623.pdf>]

'When the parents learned about it, they became furious, they beat her remorselessly and didn't let her explain the real facts. Definitely, the whole thing had to have happened as people were saying. Everything must have been her fault'

Boogart (2007) has assimilated these cases to free indirect speech sentences, which reproduce the thoughts or the words of an epistemic agent at a past time. ${ }^{5}$ Although Boogart does not adopt the anaphoric or zero tense interpretation for the imperfect, he accurately observes that such interpretations involve a temporal perspective which is simultaneous to the now of the epistemic agent whose thoughts or words are being reproduced.

However, it can be shown that modals in the imperfect may also have epistemic readings in contexts in which the imperfect cannot possibly function as an anaphoric or zero tense, most notably when embedded under a present tense form of an attitude verb:

(12) a. Jean pense que à ce moment là, Marie devait être enceinte. [FRENCH]

J. think.PRES that to that moment there M. MUST.IMPF be pregnant.

'Jean believes that Maria must have been pregnant at that time'

b. Creo que, en aquella época, el río debía estar menos contaminado

believe.PRES.1SG that in that time the river MUST.IMPF be less contaminated

que hoy en día

[SPAN.]

than today in day

'I think that at the time, the river must have been less polluted than it is nowadays'

\footnotetext{
${ }^{5}$ But see Homer (2010) for a different opinion, based on the fact that such examples do not comply with all the requirements for free indirect speech.
} 
In (12a) and (12b), the relevant epistemic agent is the subject of the attitude (Jean in (12a), the Speaker in (12b)), and the relevant time is the time of the attitude, a time which coincides with speech time. These sentences are not reporting past, but present thoughts of the epistemic agent with regard to a past situation. The imperfect is functioning as a bona fide past tense, but it is not locating Tmod in the past, it is locating the described situation in the past. The temporal configuration of (12a) and (12b) combines a simultaneous temporal perspective with a past temporal orientation:

$\underline{\text { Tmatrix }}$ SIMUL S

\section{TPersp: Tmod SIMULTmatrix TOrien: Tprej BEFORE Tmod}

Now, the temporal configuration (13) attributed to (12a-b) is in accordance with generalizations (1) and (2) above: we obtain an epistemic reading with a simultaneous temporal perspective and a past temporal orientation. This temporal configuration, however, poses an evident compositionality problem: imperfect morphology is realized on the modal, but its past component affects temporal orientation, i.e. it locates the time of the prejacent. Attempts at solving this compositionality problem mostly involve scope inversion mechanisms (Tasmowski 1980, Stowell 2004, Borgonovo \& Cummins 2007, Demirdache \& Uribe-Etxeberria 2008 among others). We will not delve into the various mechanisms that have been proposed. It suffices to say that they all strive at aligning the overt structure represented in (14a) with the structure (14b), which best captures the temporal configuration of the epistemic interpretation:
a. [TP [T impf [Modal $[\mathrm{vP} .$.
OVERT SYNTACTIC STRUCTURE
b. Modal $[\operatorname{impf}[\mathrm{vP}$.
INTERPRETATION

The plausibility of analyses postulating that the particular past tense appearing on the modal originates or is interpreted in the prejacent, and not above the modal, is increased by an observation originally due to Tasmowski (1980): ${ }^{6}$ for an epistemic reading to emerge, the choice of the past tense form must coincide with the one that would be mandatory for the prejacent without the modal. Thus, a simple (perfective) past is the only acceptable choice in sentence (15a), and correspondingly, only the modalized sentence (15b), which replicates this choice on the modal, may have an epistemic interpretation.

\footnotetext{
${ }^{6}$ See Borgonovo \& Cummins (2006) for further evidence on the matching between tense-aspect morphology on the epistemic modal and in the corresponding unmodalized sentences.
} 
(15) a.Marie escribió/ *escribía esta novela en menos de un año.

M. write.SP/ write.IMPF this novel in less of a year

'Marie wrote this novel in less than a year'

b. Marie debió escribir esta novela en menos de un año.

[ $\sqrt{E P I S T}]$

M. MUST.SP write this novel in less of a year

'Marie must have written this novel in less than a year'

c. Marie debía escribir esta novela en menos de un año.

M. MUST.IMPF write this novel in less of a year

'Marie had to write this novel in less than a year'

The accuracy of Tasmowski's generalization has been recently questioned by Martin (2011) and Mari (2015), who argue:

(i) that there are clear counterexamples to it, in which the choice of past tense on the modal does not replicate the mandatory choice for the corresponding non modalized sentences. This is the case with individual level states, which require an imperfect (16a) and do not allow the passé composé (16b), but can give rise to an epistemic reading when the modal verb is in the passé composé (16c):

(16) a. Hélène avait les yeux bleus.

H. have.IMPF the eyes blue

'Helène was blue-eyed'

b. *Hélène a eu les yeux bleus.

H. have.PRES had the eyes blue

* 'Hélène has been blue eyed'

c. Hélène a dû avoir les yeux bleus.

H. have.PRES MUST.PP have the eyes blue

'Hélène must have been blue eyed'

(ii) that sentences with an epistemic modal in the passé composé are not equivalent to sentences in which perfect morphology is realized on the infinitive, thus contradicting an apparent prediction of scope inversion mechanisms: 
(17) a. Il a pu être recompensé de la médaille Fields quand il est

he have.PRES CAN.PP be awarded of the medal Fields when he be.PRES

rentré au CNRS.

entered to+the CNRS

b. Il peut avoir été recompensé de la médaille Fields quand il est

he CAN.PRES have been awarded of the medal Fields when he be.PRES

rentré au CNRS.

entered to+the CNRS

'He may have been awarded the Fields medal when he joined the CNRS'

Both sentences allow for an interpretation in which the temporal clause gives the time at which he was (possibly) awarded the Fields medal, but only (17b) has a second reading in which the (possible) award precedes the time of the temporal clause.

Notice that both arguments involve perfect morphology on the modal verb, to which we turn now.

\section{EPISTEMIC MODALS AND HIGHER PERFECTS.}

\subsection{VARIATION IN THE EPISTEMIC READINGS OF HIGHER PERFECTS}

By contrast with tense morphology, which in Romance is morphologically linked to person agreement morphology and thus cannot be realized on infinitives, perfect morphology can be realized on infinitives. Past temporal orientation can thus be expressed by a perfect infinitive, as in (17b) above, or by perfect morphology on the modal verb, which we will call a higher perfect, as in (17a) above. Before discussing the semantics of the two possible realization sites of perfect morphology and evaluating Mari and Martin's objections to Tasmowski's generalization, it is important to realize that there is considerable macro- and micro-variation as to the possibility of higher perfects with epistemic modals. We will successively discuss pluperfects, perfect conditionals, and present perfects in French and Spanish, in order to show (i) that there is a general tendency for French to allow or prefer higher perfects, and (ii) that there is a correlation between the acceptability of higher present perfects and the aoristic drift of the perfect.

\subsubsection{PluPERFECTS}

As illustrated in (18a-b), French admits quite freely epistemic readings with a pluperfect on the modal verb: 
(18) a. Quelqu'un avait dû le jeter dehors, mais qui ? Qui ? Qui avait pu ? somebody have.IMPF MUST.PP him throw outside, but who who who have.IMPF CAN.PP Il ne se souvenait pas.

'Somebody must have thrown him outside, but who? Who? Who could have? He didn't remember'

b. Ces pièces, il avait dû les garder these coins he have.IMPF MUST.PP them keep en se disant qu'elles prendraient de la valeur un jour. Il ne s'était pas trompé.

'Those coins, he must have saved them, assuming that their value would eventually increase. He had not been proven wrong'

The most natural Spanish translations of such examples exhibit perfect infinitives, and not higher perfects:

19. a. Alguien debía haberlo arrojado fuera, pero ¿quién? somebody MUST.IMPF have+him thrown outside but who ¿Quién podía haberlo hecho? No se acordaba' who CAN.IMPF have+it done. He didn't remember

b. Esas monedas, las debía haber conservado these coins them MUST.IMPF have keep.PP diciéndose que algún día tendrían más valor. No se había equivocado.

While epistemic readings for the sequences pluperfect+modal are frequent in French, they are extremely rare in Spanish. A search of the Davies's corpus (<corpusdel espanol.org $>$ ) gives only four clear examples - two of them from the same novel ${ }^{7}$ illustrated in (20a-b)-, a range of frequency contrasting with the dozens of examples patterning like (19a-b), and in fact as low as that of epistemic readings for sequences in which the modal bears progressive aspectual morphology, which are exceptional (21).

7 Tiempo de silencio, by L. Martín-Santos, Barcelona, Seix Barral 1961. 
(20) a. De un gran sobre de papel estraza comenzó a sacar papeles, dinero, cartas, fotografías..., varios objetos que Pedro llevaba encima

$y$ otros que habían debido coger en su domicilio.

and other.PL that have.IMPF.3PL MUST.PP take in his lodging

'From a big brown envelope he started taking out papers, money, cards, pictures...., several objects that Pedro carried on him and others that they must have picked up at his lodgings...'

b. quedaba perplejo al comprobar el extraño género de relaciones que frecuentaba este mozo, aparentemente algo descarriado del que

alguno quizá había podido oír comentarios referentes a tales

somebody maybe have.IMPF CAN.PP hear comments referring to such

y cuales aficiones literarias y tales y cuales fracasos académicos

and which tastes literary and such and which failures academic

'he remained astonished at the strange sort of people this young man consorted with, apparently dissolute young man about whom some people might have heard comments referring to these or those literary preferences and these or those academic failures'...

(21) ya había puesto en conocimiento del Ministerio Fiscal las situaciones

que se estaban pudiendo producir a tenor de las denuncias que había hecho la OCU

that REFL be.IMPF CAN.GER produce to tenor of the complaints that had made the OCU

\section{[Cortes CL-M54]}

'I had already informed the Attorney General of the situations that might have been happening according to the complaints filed by the OCU'

Informal consultation of 5 native speakers of European and American varieties confirms the preference for perfect infinitives above the pluperfect+modal sequences when the context imposes an epistemic reading. Thus, in a set of contrasting sentence pairs of the type illustrated in (22a-b) and (23ab), the (a) sequences are unanimously accepted whereas the (b) sentences are judged doubtful or less acceptable by all the consultants: 
(22) a Ofrecía en un vaso un poco de agua en la que debía haber exprimido

offered in a glass a little of water in the which MUST.IMPF have press.PP

un limón a juzgar por una pepita que flotaba en él

a lemon to judge by a seed that float.IMPF in it

b. Ofrecía en un vaso un poco de agua en la que había debido exprimir

offered in a glass a little of water in the which have.IMPF MUST.PP press

un limón a juzgar por una pepita que flotaba en él.

a lemon to judge by a seed that float.impf in it

'He offered in a glass a little water in which he might have pressed a lemon, to judge by the seed floating therein'

(23) a. Pedro admitió que al terminar la lectura el sueño lo había vencido,

y que bien podía haber dejado caer el manuscrito sobre la alfombra.

and that well CAN.IMPF have let fall the manuscript on the rug

b. Pedro admitió que al terminar la lectura el sueño lo había vencido,

y que bien había podido dejar caer el manuscrito sobre la alfombra

and that well have.IMPF CAN.PP let fall the manuscript on the rug

'Pedro admitted that, when finishing reading, sleep had overcome him, and that he might have just as well let the manuscript fall on the rug'

In sum, in pluperfect contexts there is a clear difference between French, which freely admits higher perfects and Spanish, which prefers perfect infinitives.

\subsubsection{PERFECT CONDITIONALS}

The argument involving perfects and conditional morphology is slightly more complex. Combinations of conditional morphology and the perfect can give rise either to construals of epistemic uncertainty or to counterfactual readings. Thus, sentence (24) below shows an ambiguity concerning the epistemic state of the speaker, which is resolved by the two possible continuations (i) and (ii). In the epistemic reading, the speaker does not know whether Mary won or not, in the counterfactual reading, the speaker assumes that she did not win. ${ }^{8}$

(24) Marie aurait pu gagner la course.

[FRENCH]

M. have.COND CAN.PP win the race

8 The very existence of this ambiguity casts doubt on the explanation offered in Condoravdi (2001) for the parallel ambiguity of the English sentence Mary might have won the race, which relies on covert perfect raising for generating the counterfactual reading, see Laca (2012). In fact, Condoravdi's approach predicts, contrary to fact, that higher perfects will uniformly give rise to counterfactual readings in these contexts, whereas perfect infinitives will uniformly give rise to epistemic readings. 
'Marie might have won the race'

(i) C'est une possibilité à ne pas exclure.

[EPISTEMIC] $^{9}$

'We shouldn't ignore this possibility'

(ii) Mais elle a perdu.

[COUNTERFACTUAL]

'But she lost'

This ambiguity also exists in the case of the necessity modal:

(25) Pierre aurait dû arriver chez lui ily a une heure.

P. have.COND MUST.PP arrive home him there has an hour

'Pierre should have arrived home an hour ago'

(i) Appelle pour vérifier qu'il est bien là.

[EPISTEMIC]

'Call up to check whether he's there all right'

(ii) Mais il n'y est pas encore arrivé.

[COUNTERFACTUAL]

'But he hasn't arrived yet'.

The counterfactual/epistemic ambiguity is also attested in Spanish, but in this case, it is the sequence with the perfect infinitive that exhibits the ambiguity:

(26) María ya debería haber llegado a su casa.

M. already MUST.COND have arrived at her house

'María should have arrived home by now'

(i) ¿Porqué no llamas para confirmar?

[EPISTEMIC]

'Why don't you call up to check?'

(ii) Pero no ha llegado.

[COUNTERFACTUAL]

'But she hasn't arrived'.

As discussed in Laca (2012), the epistemic-counterfactual ambiguity exhibits different patterns in French and Spanish, which are summarized in Table 1:

9 A reviewer expresses doubts as to the possibility of an epistemic reading for example (24). However, there are a host of attested examples in which the sequence aurait pu Vinf clearly conveys epistemic uncertainty, and not counterfactuality. Cf. for instance:

(i) Au vu du terrain, un hélicoptère aurait bien pu venir de derrière la colline proche sans être entendu 'Due to the characteristics of the terrain, a helicopter might well have arrived from behind the nearby hill without being heard'

(ii) Il y a eu plusieurs décès en détention, que la torture et d'autres mauvais traitements auraient pu causer ou auxquels ils auraient pu contribuer.

'There have been several deaths in custody which might have been caused by torture and mistreatment or to which the latter might have contributed' 


\begin{tabular}{|c|c|c|}
\hline & French & Spanish \\
\hline $\mathrm{MOD}_{\mathrm{COND}}+$ PERF.INF & $\begin{array}{r}\text { EPIST } \\
\quad \text { pouvoir } \\
(\sqrt{ }) \text { devoir } \\
\end{array}$ & $\sqrt{E P I S T}$ \\
\hline $\mathrm{PERF}_{\mathrm{COND}} \mathrm{MOD}+\mathrm{INF}$ & $\sqrt{\mathbb{E P I S T}}$ & 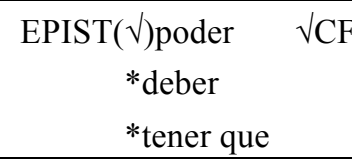 \\
\hline
\end{tabular}

Table 1: Possible construals with conditional modals and perfect mophology (from Laca 2012)

The linearizations freely allowing for the ambiguity in each language involve higher perfects in French, and perfect infinitives in Spanish. Leaving aside the complexities arising from lexical differentiation among modals, the patterns represented in the last row of Table 1 show, once again, that higher perfects in French are perfectly compatible with epistemic readings, whereas they only restrictedly receive epistemic readings (namely for the existential modal poder) in Spanish.

\subsubsection{PRESENT PERFECTS}

As illustrated in (27a-c), French freely admits epistemic readings for modals in the passé composé:

(27) a. J'ai pu me tromper.

I have CAN.PP me err

'I might have been mistaken'

b. Le voleur a dû se cacher dans l'entrée.

the thief has MUST.PP hide in the entrance

'The thief must have hidden in the entrance'

c. Hélène a dû avoir les yeux bleus.

H. has MUST.PP have the eyes blue

'Hélène must have been blue-eyed'

Spanish shows considerable variation as to the possibility of epistemic readings for modals in the perfecto compuesto. A corpus study by Vázquez Laslop (2004) demonstrates that such sequences exhibit epistemic readings in European Spanish in 264 ocurrences out of a total of $422(62,6 \%)$, whereas in Mexican Spanish they only exhibit epistemic readings in 1 occurrence out of a total of $31(3,2 \%)$. These results indicate (i) that modals in the perfecto compuesto show an overall much lower frequency in Mexican Spanish $(n=31)$ than in European Spanish $(n=422)$ and (ii) that epistemic readings for such sequences are much less frequent in Mexican Spanish (3,2\%) than in European Spanish (62,6\%).

A search of the Davies's corpus confirms these results. Epistemic readings for modals in the perfecto compuesto are attested mainly in examples from European Spanish (28a-b) and from Andean Spanish (29a-b), and are practically non-existant in other varieties. 
(28) a. podemos afirmar que, como hemos obrado así, ése ha debido ser el motivo we can assert that, since we have acted thus this has MUST.PP be the reason

'We are in a position to assert that, since we have thus acted, this must have been the reason'

b. Si incluimos a aquellos que han sido desplazados dentro de sus propios países, la cifra se aproxima a los 50 millones de personas

que han podido ser obligadas a dejar sus hogares en todo el mundo

that have CAN.PP be forced to leave their homes in all the world

'If we also count those that have been displaced inside their home countries, the numbers approach the 50 million people worldwide who may have been forced to quit their homes' .

(29) a. Somoza ha podido ser un criminal sangriento

S. has CAN.PP be a criminal bloody

o lo que usted quiera, pero no es un hombre inculto [Habla Culta, La Paz]

'Somoza may have been a bloody criminal or what you'd like to call him, but he is not an uncultivated man'

b. entonces el gasto de taxi ha debido ser grande [Habla Culta, La Paz]

then the expense of taxi has MUST.PP be big

'Then taxi expenses must have been considerable'

This internal variation in Spanish is clearly correlated with variation in the distribution and interpretation of the perfecto compuesto accross Spanish varieties. It is an established fact (see, among others, Real Academia Española 2009, Laca 2010, Howe 2013) that the perfecto compuesto in American varieties only exhibits specific aspectual values, whereas it is well advanced on the grammaticalization path known under the label of 'aoristic drift of the perfect' (Squartini \& Bertinetto 2000) in most European Spanish varieties. As shown in example (30), the perfecto compuesto can appear in typical aoristic (perfective past) contexts in such varieties:

(30) Esta mañana cuando he salido al jardín Gladys me ha llamado, como anoche. Ya estaba fuera, esperándome. He ido a su instalación, me he asomado a la ventana de su dormitorio y, ¿adivinas lo que he visto entre sus patas? (Real Academia Española: Banco de datos (CREA) [online]. Corpus de referencia del español actual. $<$ http://www.rae.es> [IX-2008])

'This morning, when I went into the garden Gladys called me, as last night. She was already outside, waiting for me. I went to her cabin, peeked through her bedroom window and guess what I saw between her paws?'

The perfectos compuestos in this fragment are combined with temporal adverbials not containing the time of utterance ('this morning'), they appear in temporal clauses ('when I went out'), they are modified by temporal clauses ('she called me when I went out'), and they constitute a narrative sequence. These are precisely the contexts that are incompatible with (aspectual) perfect semantics, and indicate the existence 
of (temporal) simple past values. Uses of the perfecto compuesto of this type are only possible in (most) European Spanish varieties.

It is thus possible to establish a correlation between the possibility of epistemic readings for a modal in combination with a higher perfect and the aoristic drift of the perfect. This correlation is reinforced by the comparison with French, which, as we saw, freely admits epistemic readings for modals in the passé composé: the French passé composé has for all practical purposes completed the aoristic drift, and can function as a simple past tense.

The explanation for the existence of epistemic readings for modals in the perfecto compuesto in Andean varieties is different, and has to do with the rise of evidential values for perfect forms in such varieties (see Howe 2013). It is the match between these evidential values and the inferences conveyed by modals in epistemic readings that could account for the existence of such combinations. ${ }^{10}$

We would like to add that microvariation as to the possibility of epistemic readings for modals with higher perfects is also attested for Italian. In fact, Mari (2015: 178 \& passim) observes that Italian shows variation as to the possibility of epistemic readings with the possibility modal potere 'can' in the passato prossimo and explicitly invokes an ongoing linguistic change. According to her hypothesis, this change involves a lexico-syntactic property of the modal, which would gradually evolve from a control to a raising verb. For reasons of space, we cannot go into the details of her hypothesis, but it is important to bear in mind that, next to the hypothetical change of status of the modal verb, Italian exhibits a well documented evolution in the use and interpretation of the passato prossimo, which places it somewhere between Spanish and French on the process of aoristic drift (cf. Squartini \& Bertinetto 2000).

Epistemic readings for higher perfects are also sporadically attested in Dutch (Boogart 2007) and in some Norwegian dialects (Eide 2001), both of which are languages exhibiting a past-tense-like present perfect. Curiously, the Norwegian dialects are characterized by a form of 'perfect doubling', combining the higher perfect on the modal with a perfect participle on the embedded verb:

(31) Han har måtta arbeidd med det i heile natt.

[NORWEGIAN]

he has must.PERF work.PERF on it in all night

'He must have worked on it all night through.' (Eide 2001, 233-4)

'Perfect doubling' appears sporadically in contemporary French, as shown in (32a-b), but a google search shows that the vast majority of such examples date from the 18th and 19th century (33a-b):

${ }^{10}$ In fact, we predict that in varieties that make frequent use of evidential values for the perfecto compuesto, it will be possible to obtain epistemic readings for modals in the perfecto compuesto. This prediction stands to be tested, taking into account that evidential values for the perfecto compuesto do exist in varieties other than the Andean varieties. 
(32) a. Le premier suspect a pu avoir été en contact avec Coulibaly, the first suspect has CAN.PPhave be.PP in contact with C.

selon une source policière. [Le Monde 18/06/2015]

'The first suspect might have been in contact with Coulibaly, according to police sources'

b. Elle a dû avoir été piquée partout,

she has MUST.PP have be.PP sting.PP everywhere

car son corps était tout boursouflé [Europe 1 21/08/2013]

'She must have gotten stung all over, since her body was all swollen'

(33) a. l'on est parfaitement convaincu que le marquis de Castries

$\mathrm{n} \quad \mathrm{a}$ pu avoir parlé ainsi [1782]

not has CAN.PP have talk.PP thus

'Everybody is fully convinced that the Marchess of Castries cannot have talked in this way'

b. Hégésippe vivoit dans ce tems-là, \&

n'a dû avoir écrit ces Discours que six ans après [1737]

not has MUST.PP have write.PP these speeches that six years after

'Hegesippe lived in that time, and he must have written these speeches six years later at the earliest'

A question that certainly deserves further research concerns the likelihood of 'perfect doubling' as a stage in the development of higher perfects in epistemic readings. If this is indeed the case, the process by which such higher perfects come into existence shows a tantalizing analogy to the better known process of externalization of inflection, by which inflectional morphology that becomes trapped between a stem and other morphological material migrates towards the edge of the word (Haspelmath 1993). Revealingly, in intermediate stages this process involves doubling of the inflectional material, which appears both at its original site and at the edge of the word. Mutatis mutandis, in the case of perfect morphology, we would have perfect morphology which has acquired past-tense-like properties and is trapped in the infinitival complement of the modal migrating towards the standard site of realization of tense morphology, the inflection on the modal. ${ }^{11}$ At the present moment, this is only a speculative suggestion, but it may give rise to a line of research which we think is worth pursuing.

\subsection{HIGHER PERFECTS AND TASMOWSKI'S GENERALIZATION}

11 Notice that Italian seems to resort to "perfect doubling" quite freely. Thus, Mari (2015) cites a number of examples like:

(i) Jean a potuto avere spostato la macchina

Jean has CAN.PP have move.pp the car

'Jean might have moved the car' 
Recall that Tasmowski's generalization states that the choice of past tense on a modal in an epistemic reading replicates the choice that would be mandatory for the prejacent in the absence of a modal verb, and suggests that the past tense in some way originates in the prejacent. Two types of counterexamples have been put forward by Mari (2015) and Martin (2011). The first type of counterexample involves realization of the passé composé on a modal in cases in which the prejacent would require an imperfect. We will call these cases non-conform higher perfects. The second type of counterexample involves cases where there is a semantic difference between the higher perfect and the corresponding sequence with a perfect infinitive. We will call these cases non-equivalent higher perfects.

\subsubsection{NON-CONFORM HIGHER PERFECTS}

As stated above (see section 2), individual level states require an imperfect (34a) and do not allow the passé composé (34b), but can give rise to an epistemic reading when the modal verb is in the passé composé (34c):

(34) a. Hélène avait les yeux bleus.

H. have.IMPF the eyes blue

'Helène was blue-eyed'

b. *Hélène a eu les yeux bleus.

H. have.PRES had the eyes blue

'Hélène has been blue eyed'

c. Hélène a dû avoir les yeux bleus.

H. have.PRES MUST.PP have the eyes blue

'Hélène must have been blue eyed'

This phenomenon also arises with other state verbs. Homer (2010) observes that the passé composé with some states gives rise to a coerced interpretation, so that (35) only has a reading in which the house cost 100.000 euro and was bought for that prize, the buying event supervening on the property of having such a prize: ${ }^{12}$

(35) Cette maison a couté 100.000 euros.

this house has cost 100.000 euro

However, pace Homer, with an epistemic modal in the passé composé, the coerced eventive reading easily disappears. Thus, (36) does not imply that the house was bought at all:

\footnotetext{
12 As pointed out by one of the reviewers, the coerced eventive reading is clearly preferred, but a stative reading is not categorically excluded, as assumed by Homer.
} 
(36) A l'époque, cette maison a dû coûter environ un million d'euros.

at the time, this house has MUST.PP cost around one million of euro

Pas étonnant qu'ils n'aient pas trouvé d'acheteur.

'At the time, this house must have cost around 1 million euro. No wonder they did not find a buyer'

Non-conform higher perfects pose a serious problem for Tasmowski's generalization in its original formulation, which requires a match between the tenses that appear in the the modalized and in the unmodalized sentence. But it is less of a problem for a refinement of this generalization, according to which this match reflects the fact that morphology that originates in the infinitival complement of the modal verb raises to be expressed on the modal. In this case, this would mean that a structure containing a perfect infinitive is transformed into one containing a higher perfect:
a. MODAL + PERFECT INFINITIVE
b. PERFECT MODAL + INFINITIVE

Now, as correctly pointed out by Martin (2011), the aspectual makeup of perfect infinitives is underspecified by comparison with the aspectual makeup of perfect tenses: perfect infinitives can have perfect(ive) or imperfective readings. As shown by the choice of tenses in the (a) and the (b) sentences in each pair, imperfective readings arise not only with infinitives as complements of modals (38a-b), but also in other contexts (39a-b, 40a-b):

a. \#Pierre a été albinos.

P. has been albinos

b. Pierre peut très bien avoir été albinos.

P. may very well have been albinos

(39) a. Le Colosse de Rhode pesait/ \#a pesé trois tonnes.

The Colossus of Rhodes weigh.IMPF /\# has weighed three tons

'The Colossus of Rhodes weighed three tons'

b. Le Colosse de Rhode est censé avoir pesé trois tonnes.

'The Colossus of Rhodes is thought to have weighed three tons' 
(40)
a. Il dit qu'il ignorait /\#a ignoré l'existence de cet enfant.
he says that he ignore.IMPF/\# has ignore.PP the existence of this child
'He says that he was not aware of this child's existence'
b. Il dit avoir ignoré l'existence de cet enfant.
he says to+have ignore.PP the existence of this child
'He pretends not to have been aware of this child's existence'

If higher perfects have their origin in a perfect which is generated on the infinitive, and are attracted by the modal verb by a sort of overt perfect raising mechanism, examples like (34c) and (36) do not pose more of a problem than examples like (38b): the higher perfects inherit the aspectual makeup of the perfect infinitives, which, as we have just shown, may have imperfective readings. Recall that in the last section we have surmised that the existence of "perfect doubling" may indicate that such a mechanism is or has been at work in French.

\subsubsection{NON-EQUIVALENT HIGHER PERFECTS}

However, the hypothesis of a perfect raising mechanism is now confronted to the second objection raised by Mari (2015), namely that one can devise contexts in which higher perfects are not equivalent to the corresponding sequences with perfect infinitives. Counterexamples of this kind follow always the same pattern: the sequence with the perfect infinitive has an extra reading corresponding to a temporal configuration which is impossible with the higher perfect.

Thus, for instance, (41b) has a reading in which he might have already been awarded the Fields medal when he joined the CNRS, whose temporal configuration is represented as (42). This temporal configuration cannot be associated with (41a), which, according to Mari (2015), only admits the interpretation in which the time of the award coincides with the time at which he joined the CNRS.

(41) a. Il a pu être recompensé de la médaille Fields quand il est he have.PRES CAN.PP be awarded of the medal Fields when he be.PRES rentré au CNRS.

entered to+the CNRS

b. Il peut avoir été recompensé de la médaille Fields quand il est he CAN.PRES have been awarded of the medal Fields when he be.PRES rentré au CNRS. entered to+the CNRS

'He may have been awarded the Fields medal when he joined the CNRS' 
(42)

--------he be awarded -------------he join the CNRS------------S
the Fields medal
Tmod

Analogously, (43a) is acceptable because it allows for a temporal configuration (44) in which the (possible) event of getting a promotion precedes 'tomorrow', but not Speech Time, whereas the event can only precede Speech Time in the case of the anomalous (43b):
a. Il peut
avoir reçu
sa promotion demain
et
he CAN.PRES have gotten his promotion tomorrow and quand même changer d'entreprise tout de suite après nonetheless change of enterprise all of sequence after b. *Il a pu recevoir sa promotion demain et he has CAN.PP get his promotion tomorrow and quand même changer d'entreprise tout de suite après [ex. from Mari 2015 :210] nonetheless change of enterprise all of sequence after

'He may have gotten his promotion by tomorrow and nonetheless change companies right after that'

(44) S---------he get a promotion-----tomorrow-----he change company Tmod

Note first that the temporal configuration (44) is actually a future perfect configuration. Whereas both (41b) and (43a) share a simultaneous temporal perspective, (41b) has a past temporal orientation, but (43a) has a future temporal orientation. Now, as stated in section 1 above, there is consensus as to the existence of epistemic readings for decided issues (propositions whose truth value depends on facts which are past or simultaneous wrt. Tmod), but there is an ongoing debate as to the wisdom of attributing the label 'epistemic' to readings in which, due to the indeterminacy of the future, the subjective uncertainty characterising epistemic readings goes hand in hand with the objective uncertainty pertaining to contingent futures (cf. Condoravdi 2001, Portner 2009, 222-236).

Leaving aside the issue of the debatable epistemic status of (43a), what Mari's counterexamples actually show is that the anteriority relation conveyed by the perfect can only be computed with regard to Speech Time in the case of a higher present perfect, but it can also be computed with regard to a temporal adverbial clause or a temporal adverb in the case of a perfect infinitive. Anchoring the anteriority relation to the temporal adverbial clause in (41b) produces the pluperfect-like configuration in (42), anchoring it to the temporal adverb in (43a) produces the future-perfect-like configuration in (44). Crucially, what Mari's counterexamples do not show is that there is a difference in temporal perspective between (41a) and (41b) or between (43a) and (43b). And Tasmowski's generalization and its refinement target precisely the possibility of mantaining a simultaneous temporal perspective for epistemic readings when the modal verb bears past or perfect morphology.

To sum up, Martin's and Mari's counterexamples, while undoubtedly contributing to refine Tasmowski's generalization, do not offer conclusive evidence for the existence of a past temporal perspective in epistemic readings of modals bearing past or perfect morphology. They show, however, that -at least in the case of perfects- Tasmowski's generalization should be better formulated as "perfect 
raising", correlating perfect infinitives with higher perfects, and not as as a sort of "copying" on the modal of a tense which has its origin in the unmodalized version of the sentence. They also show that higher perfects, which are necessarily tensed, do not have the same privileges of occurrence and interpretation as perfect infinitives, which are necessarily non-tensed. ${ }^{13}$

\section{CONCLUding Remarks}

In this paper, we have examined the hypothesis that modal verbs in epistemic readings require a simultaneous temporal perspective in the light of the morphological evidence from Romance languages, in which modal verbs are fully inflected for TMA categories, paying particular attention to the interaction of modal verbs with perfect morphology.

We have first shown that the semantic formulation of the hypothesis, based on the type of temporal perspective required, fares much better than the syntactic formulation, which requires epistemic modals to outscope tense. In fact, the semantic contrast between a deictic tense (the present) and an anaphoric tense (the imperfect) evidenced by epistemic modals demonstrates that tense morphology on modals is interpretable. Secondly, starting from Tasmowski's observation as to the matching tense-aspect categories of modals in epistemic readings and of the corresponding unmodalized sentences, we have compared the linearizations of perfect morphology in French and Spanish by contrasting perfect infinitives with higher perfects. We have been able to show that Spanish exhibits a clear preference for the former, whereas French shows a clear preference for the latter, thus indicating the existence of variation. This variation is probably due to a diachronic process of perfect raising which correlates with the 'aoristic drift' of the perfect. Finally, we have discussed the counterexamples to Tasmowski's generalization put forward by Mari (2015) and Martin (2011), showing that, although they contribute to refine Tasmowski's generalization, which should be interpreted in terms of perfect raising, they do not provide decisive arguments against the hypothesis that epistemic readings require a simultaneous temporal perspective.

If the idea of perfect raising suggested by our materials is on the right track, much further work on larger databases is required in order to adequately describe this process. It should be stressed that the picture that emerges from our materials, particularly from the comparison of different varieties, is not necessarily one of a (synchronic) syntactic derivation, by means of which higher perfects are derived from perfect infinitives, but rather that of a diachronic process of syntactic change, producing alternative linearisations with nearly equivalent temporal interpretations.

\section{REFERENCES}

Boogaart, R., 2007. The past and perfect of epistemic modals, in L. de Saussure, J. Moeschler \& G. Puskas (eds.) Recent advances in the syntax and semantics of tense, aspect, and modality. Berlin, Mouton-de Gruyter, 47-71.

\footnotetext{
${ }^{13}$ Martin (2011) discusses a number of revealing contrasts between higher perfects and perfect infinitives which -we believe- can all be explained by (i) the fact that higher perfects, being tensed, are always anchored to Speech Time in matrix contexts, and (ii) the fact that perfect infinitives have a less specified aspectual contour than tensed perfects.
} 
Borgonovo, C. \& Cummins, S., 2007. Tensed Modals, in J. Eguren, O. Fernández Soriano, (eds.), Coreference, Modality, and Focus, Amsterdam, John Benjamins, 1-18.

Bosque, I., 1999. ¿Qué sabe el que sabe hacer algo? Saber entre los predicados modales, in K. Korta \& F. García Murga, (eds.), Palabras. Victor Sánchez de Zavala in memoriam. Filosofía 3 (EHU), 303-323.

Butler, J., 2004. Phase Structure, Phrase Structure, and Quantification, PhD Dissertation, University of York.

Cinque, G., 1999. Adverbs and Functional Heads. A Cross Linguistic Perspective, Oxford, Oxford University Press.

Condoravdi, C., 2001. Temporal interpretations of modals. Modals for the present and for the past, in D. Beaver et al. (eds.), The Construction of Meaning, Stanford,CSLI Publications, 59-88.

Demirdache, H. \& Uribe-Etxeberria, M., 2006. Scope and anaphora with time arguments: the case of 'perfect modals', in H. Harley \& R. Folli, (eds), Lingua 118.

Demirdache, H. \& Uribe-Etxeberria, M., 2008. Morfosintaxis e interpretación de los verbos modales, in A. Carrasco Gutiérrez, (ed.), Tiempos compuestos y formas verbales complejas, Madrid-Frankfurt, Iberoamericana.

Desclés, J.-P. \& Guentcheva, Z., 2001. La notion d'abduction et le verbe devoir "épistémique", in P. Dendale, P. \& J. van der Auwera (eds.), Les verbes modaux. Cahiers Chronos 8, Amsterdam, Rodopi.

Hacquard, V., 2006. Aspects of Modality, Ph.D. dissertation, MIT.

Haspelmath, M., 1993. The diachronic externalization of inflection, Linguistics 31, 2. 279-309.

Homer, V., 2010. Epistemic modals: High ma non troppo, Proceedings of NELS 40.

Howe, C. L., 2013. The Spanish perfects: pathways of emergent meaning, London, Palsgrave-Macmillan. Davies, M., 2002-2015. Corpus del español, <www.corpusdelespanol.org>.

Eide, K.M., 2001. Norwegian modals, Berlin, Mouton/de Gruyter.

von Fintel, K., 2005. Modality and Language, in Encyclopaedia of Philosophy, 2nd edition.

von Fintel, K. \& Gillies, A., 2007. An Opinionated Guide to Epistemic Modality, in T. Gendler \& J.

Hawthorne, J. (eds.), Oxford Studies in Epistemology, Oxford, Oxford University Press, 36-62.

Guéron, J. \& Lecarme, J.(eds), 2004. The Syntax of Time, Cambridge, Mass., MIT Press.

Guéron, J. \& Lecarme, J. (eds), 2008. Time and Modality, Berlin, Kluwer.

Kaufmann, S., Condoravdi, C. \& Harizanov, V., 2006. Formal approaches to modality, in W. Frawley (ed.) The expression of modality, Berlin, Mouton-De Gruyter.

Kratzer, A., 2012. Modals and conditionals, Oxford, Oxford University Press.

Laca, B., 2009. Perfect semantics. How universal are Ibero-American Present Perfects?, in C. Borgonovo $\&$ al. (eds.) Selected Proceedings of the Hispanic Symposion, Laval, ed. Cascadilla Press. 1-16.

Laca, B., 2012. On modal tenses and tensed modals, in C. Nishida \& C. Russi (eds.), Building a bridge between linguistic communities of the Old and the New World, Cahiers Chronos 25, Amsterdam, Rodopi, 163-198.

Laca, B., 2014. Epistemic modals and temporal anchoring, ReVEL 8, Special Issue on Modality, $<$ www.revel.inf.br>

Mari, A., 2015, Modalités et temps. Modèles et données, Bern, P. Lang.

Martin, F., 2011. Epistemic modals in the past, in J. Berns \& al. (eds.) Romance Languages and Linguistic Theory 9, Amsterdam, Benjamins.

Papafragou, A., 2005. Epistemic modality and truth conditions, in A. Klinge \& Müller, (eds.), Perspectives on Modality, Amsterdam, John Benjamins, 1688-1702.

Picallo, C., 1990. Modal verbs in Catalan. Natural Language and Linguistic Theory 8(2), 285-312.

Portner, P., 2009. Modality, Oxford, Oxford University Press. 
Real Academia Española, 2009. Nueva gramática de la lengua española, Madrid, Espasa Calpe.

Squartini, M. \& Bertinetto, P.M., 2000. The Simple and compound past in Romance languages. In O. Dahl (ed.), Tense and aspect in the languages of Europe, Berlin, Mouton/de Gruyter, 405-475.

Stowell, T., 2004. Tense and Modals, in J. Guéron \& J. Lecarme, (eds.), 621-636.

Tasmowski, L., 1980. Un devoir épistémique. Travaux de linguistique 7, 43-58.

Vázquez Laslop, M.E., 2004. Modalidad de deber (de) + Infinitivo en antepresente: México frente a España. ms. México. El Colegio de México.

Werner, Th., 2003. Deducing the Future and Distinguishing the Past: Temporal Interpretation in Modal Sentences in English, PhD Dissertation, Rutgers University. 